\title{
Evaluasi Efisiensi Penyelenggaraan Pendidikan di Indonesia Menggunakan Metode Data Envelopment Analysis. Studi Kasus: Jenjang Sekolah Menengah Kejuruan Tahun 2018
}

\author{
Ilun Tisrinasari, Syarifa Hanoum, dan Anandita Ade Putri \\ Departemen Manajemen Bisnis, Institut Teknologi Sepuluh Nopember (ITS) \\ e-mail: syarifa.hanoum@gmail.com
}

\begin{abstract}
Abstrak — Sumber daya manusia merupakan faktor penting dalam perekonomian suatu negara, salah satu cara untuk memeroleh sumber daya manusia yang berkualitas adalah dengan penyelenggaraan sistem pendidikan yang berkualitas pula. Pendidikan termasuk dalam pertimbangan penting yang diupayakan pemerintah, terbukti dari besarnya anggaran yang diperuntukan untuk pendidikan. Oleh karena itu, mengevaluasi efisiensi penyelenggaraan pendidikan di Indonesia diperlukan untuk dapat mengetahui kondisi kinerja sektor pendidikan. Salah satu jenjang pendidikan di Indonesia adalah jenjang sekolah menengah kejuruan, jenjang ini merupakan jenjang pendidikan yang bertujuan menyiapkan lulusan yang siap untuk bekerja. Tujuan penelitian ini dapat diselesaikan menggunakan metode Data Envelopment Analysis (DEA). Penelitian ini akan mengukur jenjang pendidikan sekolah menengah kejuruan pada tahun 2018. Hasil penelitian menunjukkan bahwa terdapat 14 provinsi pada sekolah menengah kejuruan yang mengalami efisiensi. Selain itu, diperoleh juga referensi dan perbaikan untuk provinsi yang belum efisien, salah satunya pada Provinsi Maluku Utara yang memiliki nilai terkecil. Analisis skala efisiensi juga menunjukkan bahwa sebagian besar provinsi beroperasi dalam skala decreasing return to scale.
\end{abstract}

Kata Kunci-Data Envelopment Analysis, Efisiensi, Pendidikan, SMK, Provinsi di Indonesia

\section{PENDAHULUAN}

$\mathrm{S}_{\mathrm{p}}^{\mathrm{u}}$ UMBER daya manusia merupakan faktor penting dalam $\checkmark$ perekonomian suatu negara, sumber daya yang berkualitas dapat diperoleh salah satunya dari penyelenggaraan sistem pendidikan yang berkualitas pula. Saat ini Indonesia menempati posisi ke-87 dari 157 negara berdasarkan Human Capital Index 2018 yang dikeluarkan oleh World Bank. Sebagai perbandingan, Singapura menduduki peringkat pertama. Indeks ini mengombinasikan sejumlah komponen, salah satunya kualitas dan kuantitas pendidikan [1]. Pendidikan menjadi pertimbangan penting yang diusahakan oleh pemerintah, seperti yang tertuang dalam UUD 1945 pasal 31 ayat 1 yang berbunyi "Setiap warga negara berhak mendapat pendidikan". Mengindikasikan bahwa adanya upaya perluasan akses dan pemerataan pendidikan. Pada realitasnya, isu mengenai masalah pendidikan seperti akses pendidikan dan pemerataan masih dirasa kurang optimal [2].

Penyelenggaraan pendidikan menjadi salah satu strategi untuk dapat meningkatkan pertumbuhan ekonomi Indonesia.
Pemerintah berkomitmen untuk meningkatkan kualitas dari sumber daya manusia dengan mengalokasikan dana pendidikan sejumlah 20 persen dari Anggaran Pendapatan dan Belanja Negara (APBN) sesuai dalam amanat UUD Pasal 31 ayat 4. Anggaran fungsi pendidikan merupakan yang terbesar diantara kementerian/lembaga lainnya (Kementerian Perencanaan Pembangunan Nasional/Badan Perencanaan Pembangunan Nasional, 2017). Alokasi dana yang besar tersebut dinilai belum optimal dalam meningkatkan dan pemerataan kualitas pendidikan di Indonesia [3].

Angka partisipasi sekolah di Indonesia bernilai positif dengan adanya kenaikan tiap tahunnya. Angka partisipasi sekolah di tiap-tiap provinsi di Indonesia juga meningkat tiap tahunnya, hanya saja persentase pada masing-masing provinsi berbeda. Pada tahun 2018 data BPS menunjukan untuk kelompok usia 7-12 tahun memiliki persentase terendah pada provinsi Papua dengan 99,07 persen dengan nilai tertinggi APS ada pada provinsi Yogyakarta dengan nilai 99,9 persen. Pada kelompok usia 13-15 tahun, nilai persentase terendah 80 persen dan tertinggi 97,92 persen. Kelompok usia 16-18 tahun terendah 63,48 persen dan yang tertinggi 88,93 persen. Pada data BPS 2018, provinsi dengan nilai APS tertinggi adalah provinsi Daerah Istimewa Yogyakarta. Hal tersebut mengindikasikan bahwa daerah tersebut akses pendidikannya sudah meluas. APS terendah pada provinsi Papua. Adanya selisih APS antar provinsi mengindikasikan belum meratanya akses pendidikan di Indonesia. Salah satu jenjang pendidikan di Indonesia adalah sekolah menengah kejuruan, yang bertujuan untuk mencetak lulusan yang lebih banyak praktek dibandingkan dengan teori. SMK dirasa lebih menjanjikan mengingat kondisi perekonomian Indonesia yang masih bertumbuh dan dunia kerja yang semakin kompetitif.

Beberapa penelitian telah mengukur efisiensi pada penyelenggaraan pendidikan di Indonesia. Salah satunya, penelitian dari Siti Fatimah dan Umi Mahmudah (2017a) yang menginvestigasi efisiensi jenjang sekolah dasar di tiap-tiap provinsi di Indonesia menggunakan Data Envelopment Analysis yang (DEA) [4]. Hasil penelitian menunjukan bahwa ada 47,06 persen dari keseluruhan sekolah dasar yang bekerja dengan efisien, dan sisanya berada pada kondisi inefisien. Penelitian pada jenjang SMP oleh Hadi Mahmudi, Munawar Ismail, Candra Fajri Ananda dan Moh. Khusaini (2014) 
melakukan analisis efisiensi teknis pada SMP di kota Mataram [5]. Penelitian terbaru oleh Umi Mahmudah, Suhartono dan Rohayana (2018) mengevaluasi efisiensi teknis pada sekolah menengah atas di Indonesia pada tiap provinsi menggunakan DEA, hasilnya hanya 11 provinsi di Indonesia yang sudah mencapai nilai efisien [6]. Dapat disimpulkan dari penelitianpenelitian tersebut bahwa penggunaan DEA sesuai dalam mengukur pemerintah provinsi pada efisiensi sekolah di Indonesia. Penelitian tersebut didukung oleh penelitian Arinto Haryadi (2011) yang melakukan analisis efisiensi teknis bidang pendidikan pada setiap jenjang pendidikan di Indonesia. Hasil penelitian tersebut membuktikan hipotesis bahwa terjadi inefisiensi dalam penyelenggaran pendidikan di Indonesia baik secara teknis biaya maupun teknis sistem [7].

Alokasi dana pendidikan yang begitu besar perlu dikelola dengan efektif dan efisien. Tidak hanya melakukan efisiensi teknis biaya, diharapkan penelitian ini mampu memberikan gambaran mengenai rekomendasi efisiensi teknis sistem pada penyelenggaran pendidikan di Indonesia. Efisiensi teknis sistem dapat membantu mengalokasikan sumber daya sehingga tercipta pemerataan pendidikan dan peningkatan akses pendidikan di Indonesia.

\section{II.LANDASAN TEORI}

\section{A. Pengertian Kinerja}

Konsep kinerja sudah banyak dikemukakan oleh beberapa ahli. Kinerja adalah hasil kerja yang dicapai oleh individu maupun kelompok dalam suatu organisasi atau entitas sesuai dengan tanggung jawab dan wewenang untuk mencapai tujuan organisasi yang legal, tidak melanggar suatu hukum, moral dan etika yang berlaku [8]. Menurut Agung et al., (2008) menyebutkan kinerja adalah hasil evaluasi terhadap pekerjaan dibanding dengan target capaian yang sudah ditetapkan [9]. Mulyadi (2007) menambahkan kinerja adalah suatu keberhasilan anggota sebagai individu, tim atau organisasi dalam mewujudkan sasaran strategi yang sudah ditetapkan [10]. Sehingga dapat disimpulkan kinerja adalah capaian yang diperoleh suatu organisasi atas sebagian atau seluruh tindakan dan aktivitas yang telah diupayakan pada suatu periode tertentu. Capaian tersebut diukur berdasarkan target yang sudah ditetapkan sejak awal yang menjadi landasan dalam langkah strategis organisasi.

\section{B. Pengukuran Kinerja Berbasis Efisiensi}

Salah satu cara dalam mengukur kinerja adalah dengan menggunakan konsep efisiensi. Efisiensi merupakan salah satu parameter kinerja yang mendasari seluruh kinerja suatu organisasi [11]. Pengukuran parameter kinerja tersebut diharapkan dapat menghasikan output semaksimal mungkin dengan input yang tersedia. Pada saat pengukuran efisiensi dilakukan dengan menghitung tingkat output yang optimal dengan tingkat input yang tersedia atau dengan menilai tingkat input yang minimum untuk menghasilkan output tertentu. Dalam proses tersebut akan dapat mengidentifikasi penyebab inefisien dari suatu proses aktivitas. Efisiensi mengacu pada filosofi bahwa kemampuan menghasilkan suatu output yang paling optimal dari input yang tersedia.

\section{Data Envelopment Analysis}

Data Envelopment Analysis adalah sebuah metodologi nonparametrik yang didasarkan pada linear programming, melalui sebuah pemetaan frontier produksi yang kemudian digunakan untuk menganalisis fungsi produksi) [12]. DEA telah banyak digunakan dalam pengukuran kinerja suatu kegiatan operasional [13] . Model DEA pertama kali diperkenalkan oleh Charnes et. al., (1978) model DEA ini menggunakan asumsi kondisi constant return to scale yang berasumsi bahwa setiap DMUs telah beroperasi pada skala optimal [14]. Metode ini didesain untuk mengevaluasi performansi relatif antar Decision Making Units (DMUs). Hanoum (2004) menjelaskan DMU merupakan unit-unit analisis sebagai entitas yang bertanggungjawab mentransformasikan input menjadi output [15].

\section{1) Jenis Asumsi Metode DEA}

Dalam pengukuran efisiensi dengan menggunakan DEA terdapat dua asumsi yang sering digunakan, yaitu:

a) Constant Return To Scale

Model CCR ini pertama kalinya ditemukan oleh Charnes et. al., (1978). Pada model ini diperkenalkan suatu ukuran efisiensi untuk masing-masing decision making unit (DMU) yang merupakan rasio maksimum antara output yang terbobot dengan input yang terbobot. Model primal DEA yang pertama digunakan, dikenal dengan model constant return to scale (CRS) yang berasumsi bahwa setiap DMUs telah beroperasi pada skala optimal [14]. Model awal yang digunakan, dikenal dengan rasio CCR, merupakan persamaan non linier sebagai berikut.

$$
\begin{array}{ll}
\text { Max } & h_{n} \frac{\Sigma_{j} u_{j} j_{n}}{\Sigma_{j} v_{i} j x_{i n}} \\
\text { s.t } & h_{n} \frac{\Sigma_{j} u_{j} j_{n}}{\Sigma_{j} v_{i} j x_{i n}} \leq 1 \\
& u_{j} v_{i \geq \varepsilon}
\end{array}
$$

Notasi yang umum digunakan dalam model DEA adalah :

Indeks :

$$
\begin{aligned}
& n=\text { DMUs }, n=1, \ldots, N \\
& j=\text { output }, j=1, \ldots, J \\
& i=\text { input }, \quad i=1, \ldots, I
\end{aligned}
$$

Data :

Variabel :

$y_{j n}=$ nilai dari output ke- $j$ dari DMU ke $n$

$x_{i n}=$ nilai dari input ke- $i$ dari DMU ke $n$

$\varepsilon=$ angka positif yang kecil

\section{b) Variable Return To Scale}

$u_{j}, v_{i}=$ bobot untuk output $j$, input $i(\geq \varepsilon)$

$h_{n} \quad=$ efisiensi relatif $\mathrm{DMU}_{\mathrm{n}}$

Pada model CRS yang telah dijelaskan, model ini berasumsi bahwa semua DMUs berada pada skala optimal, sedangkan terdapat kondisi yang memungkinkan membuat DMUs tidak dapat berkompetisi pada skala yang optimal. Oleh sebab itu, Banker et. al., (1984) menyarankan pengembangan model DEA-CRS dalam situasi variable return to scale (VRS) [16]. Agar variabel return terskala, maka perlu ditambahkan kondisi convexity bagi nilai-nilai bobot $\lambda$, yaitu dengan memasukan 
dalam model di atas batasan berikut:

$$
\sum_{n} \lambda_{n}=1
$$

\section{2) Jenis Orientasi Metode DEA}

Pengukuran efisiensi dengan menggunakan DEA umumnya menggunakan dua orientasi target perbaikan, yaitu:

a) Input-Oriented Measures

DEA yang berorientasi pada input, model pemrograman linier dikonfigurasikan untuk menentukan berapa banyak input yang digunakan perusahaan dapat dihemat/dikurangi jika digunakan secara efisien untuk mencapai tingkat output yang sama.

b) Output-Oriented Measures

DEA yang berorientasi pada input, model pemrograman linier dikonfigurasikan untuk menentukan output potensial yang bisa dihasilkan jika menggunakan sejumlah input yang sama (tetap) yang beroperasi secara efisien.

\section{D.Peer Group}

Peer group dilakukan untuk menentukan DMU yang akan menjadi acuan bagi DMU yang tidak efisien dengan menentukan target efisiensinya (perbaikan efisiensinya). Beberapa DMUs dengan tingkat efisiensinya masih relatif rendah dapat diperbaiki dengan mengacu pada DMUs lainnya yang relatif sudah efisien. Penetapan target input maupun output perbaikan dapat dihitung dengan mengalikan bobot peer group dengan input maupun output DMU yang dijadikan acuan (Nugroho et. al., 2011). Penentuan skor efisiensi tiap unit akan dibandingkan dalam sebuah grup tertentu yang terdiri atas kombinasi linear dari efisiensi DMU-DMU terkait (Hadad et. al., 2003).

\section{E. Scale Efficiency}

Scale efficiency (SE) merupakan indikator apakah suatu DMUs telah beroperasi pada skala optimal atau tidak. Apabila nilai $\mathrm{TE}_{\mathrm{CRS}}$ sama dengan nilai $\mathrm{TE}_{\mathrm{VRS}}$ maka nilai $\mathrm{SE}$ akan sama dengan satu. Namun jika nilai SE lebih dari satu, hal itu merupakan indikasi bahwa DMU tersebut mempunyai scale inefficiency. Apabila $\mathrm{TE}_{\mathrm{VRS}}>\mathrm{SE}$ maka perubahan efisiensi (baik peningkatan maupun penurunan) dipengaruhi oleh efisiensi teknis murni. Namun, apabila $\mathrm{TE}_{\mathrm{VRS}}<\mathrm{SE}$ maka perubahan efisiensi lebih disebabkan oleh perkembangan scale efficiency [17].

\section{METODOLOGI PENELITIAN}

Metode dan Tahapan Penelitian

\section{A. Tahap Identifikasi dan Perumusan Masalah}

Tahap identifikasi dan perumusan masalah terdiri dari : (1)Identifikasi kondisi existing penyelenggaraan pendidikan terkait visi misi, proses penyelenggaraan pendidikan, pengukuran kinerja, dan pengukuran efisiensi saat ini; (2)Melakukan Studi Literatur.

\section{B. Tahap Penentuan Spesifikasi Model DEA}

Berikut akan dibahas mengenai spesifikasi model yang digunakan pada penelitian, terdiri dari empat tahapan yaitu sebagai berikut:

a. Asumsi yang digunakan pada penelitian ini adalah variable return to scale.

b. Penentuan fungsi tujuan dan target perbaikan yang digunakan pada penelitian ini, yaitu output-oriented measures.

c. Penentuan variabel input dan output yang digunakan pada penelitian, dimana variabel input antara lain alokasi pendidikan perkapita murid (ADM), angka partisipasi murni (APM), rasio guru/murid (RGM), rasio kelas/murid (RKM), sedangkan variabel output yang digunakan adalah angka melanjutkan sekolah (AM) dan angka tidak putus sekolah (100-APS).

d. Menyusun model matematis atau formulasi metode Data Envelopment Analysis (DEA)

\section{C.Tahap Analisis dan Pembahasan}

Peneliti kemudian menganalisis dan membahas terkait hasil perhitungan nilai efisiensi untuk seluruh provinsi di Indonesia. Tahap ini juga menghasilkan peer group/provinsi acuan untuk provinsi yang belum efisien serta target perbaikan untuk meningkatkan efisiensi provinsi yang belum efisien.

\section{D.Tahap Kesimpulan dan Saran}

Pada tahap ini juga akan didapatkan kesimpulan penelitian yang menyatakan kembali hasil utama dari seluruh proses penelitian yang telah diuraikan dalam bab-bab sebelumnya serta tingkat keberhasilan proses penelitian dalam mencapai tujuan yang telah ditetapkan di awal penelitian.

\section{ANALISIS DAN DISKUSI}

\section{A. Analisis Efisiensi Provinsi}

Tahap pertama dalam pengolahan data penelitian ini yaitu melakukan perhitungan efisiensi seluruh provinsi di Indonesia dengan menggunakan output-oriented VRS DEA dimana formulasi matematisnya dituliskan pada (1).

Fungsi obyektif:

Max

Fungsi pembatas:

$$
\theta_{n} \Sigma\left(\sum_{i} I S_{i}+\sum_{i} O S_{i}\right)
$$

Output 1 : Angka Melanjutkan

$$
\sum_{j} y_{1 n} \lambda_{n}-\theta_{n} y_{1 o}-O S_{1}=0
$$

Output 2: Angka Tetap Sekolah

$$
\sum_{j} y_{2 n} \lambda_{n}-\theta_{n} y_{2 o}-O S_{2}=0
$$

Input 1 : Alokasi pendidikan $\quad \sum_{i} x_{1 n} \lambda_{n}+I S_{1}=x_{1 o}$ Input 2 : Rasio Guru/Murid $\quad \sum_{i} x_{2 n} \lambda_{n}+I S_{2}=x_{2 o}$ Input 3 : Rasio Kelas/Murid $\quad \sum_{i} x_{3 n} \lambda_{n}+I S_{3}=x_{3 o}$ Input 4 : Angka Partisipasi Murni $\sum_{i} x_{4 n} \lambda_{n}+I S_{4}=x_{4 o}$ 
Tabel 4.

Hasil Perhitungan Overall Efficiency SMK

\begin{tabular}{lclc}
\hline \hline Provinsi & OE & Provinsi & OE \\
\hline DKI Jakarta & 1 & Kalimantan Tengah & 0.994 \\
Jawa Barat & 1 & Kalimantan Selatan & 1 \\
Banten & 1 & Kalimantan Timur & 0.997 \\
Jawa Tengah & 1 & Kalimantan Utara & 1 \\
DI Yogyakarta & 1 & Sulawesi Utara & 0.996 \\
Jawa Timur & 0.997 & Gorontalo & 1 \\
Aceh & 0.994 & Sulawesi Tengah & 0.995 \\
Sumatera Utara & 0.99 & Sulawesi Selatan & 0.994 \\
Sumatera Barat & 0.996 & Sulawesi Barat & 0.988 \\
Riau & 0.997 & Sulawesi Tenggara & 0.985 \\
Kepulauan Riau & 1 & Maluku & 0.993 \\
Jambi & 0.998 & Maluku Utara & 0.974 \\
Sumatera Selatan & 1 & Bali & 1 \\
Bangka Belitung & 1 & Nusa Tenggara Barat & 0.984 \\
Bengkulu & 0.989 & Nusa Tenggara Timur & 0.988 \\
Lampung & 0.998 & Papua & 1 \\
Kalimantan Barat & 1 & Papua Barat & 0.991 \\
\hline \hline
\end{tabular}

Tabel 5.

Daftar Penyederhanaan Nama Provinsi dengan Kode DMU

\begin{tabular}{clcl}
\hline \hline $\begin{array}{c}\text { Kode } \\
\text { DMU }\end{array}$ & \multicolumn{1}{c}{ Provinsi } & $\begin{array}{c}\text { Kode } \\
\text { DMU }\end{array}$ & \multicolumn{1}{c}{ Provinsi } \\
\hline 1 & DKI Jakarta & 18 & Kalimantan Tengah \\
2 & Jawa Barat & 19 & Kalimantan Selatan \\
3 & Banten & 20 & Kalimantan Timur \\
4 & Jawa Tengah & 21 & Kalimantan Utara \\
5 & DI Yogyakarta & 22 & Sulawesi Utara \\
6 & Jawa Timur & 23 & Gorontalo \\
7 & Aceh & 24 & Sulawesi Tengah \\
8 & Sumatera Utara & 25 & Sulawesi Selatan \\
9 & Sumatera Barat & 26 & Sulawesi Barat \\
10 & Riau & 27 & Sulawesi Tenggara \\
11 & Kepulauan Riau & 28 & Maluku \\
12 & Jambi & 29 & Maluku Utara \\
13 & Sumatera Selatan & 30 & Bali \\
14 & Bangka Belitung & 31 & Nusa Tenggara \\
& & & Barat \\
15 & Bengkulu & 32 & Nusa Tenggara \\
16 & Lampung & 33 & Timur \\
17 & Kalimantan Barat & 34 & Papua Barat \\
\hline \hline
\end{tabular}

$$
\sum_{n=1}^{N} \lambda_{n}=1
$$

Indeks:

$$
\begin{aligned}
& n=\text { DMU } 1, . ., \text { DMU } 18 \\
& j=\text { output } 1, . ., \text { output } 2 \\
& i=\text { input } 1, . ., \text { input } 4
\end{aligned}
$$

Data :

$y_{j n}=$ nilai dari output ke- $j$ dari DMU ke $n$

$x_{i n}=$ nilai dari input ke- $i$ dari DMU ke $n$

$\varepsilon=$ angka positif yang kecil $\left(10^{-6}\right)$

Variabel :

$$
\begin{array}{ll}
\theta_{n} & =\text { efisiensi relatif } \mathrm{DMU}_{\mathrm{n}} \\
I S_{i}, O S_{j} & =\text { slack dari input } i, \text { output } j(\geq 0) \\
\lambda_{n} & =\text { bobot DMUn }(\geq 0)
\end{array}
$$

Tabel 1 menunjukkan hasil perhitungan nilai efisiensi Provinsi dengan menggunakan output oriented VRS DEA. Berdasarkan tabel 1, terdapat 14 provinsi yang dinyatakan efisien, sedangkan 20 provinsi dinyatakan tidak efisien.

\section{B. Analisis Peer Group}

Analisis peer group dilakukan untuk menentukan dan
Tabel 1.

Hasil penentuan Provinsi acuan

\begin{tabular}{lclc}
\hline Provinsi & Provinsi acuan & Provinsi & Provinsi acuan \\
\hline DKI Jakarta & $01,03,04$ & Kalimantan Tengah & - \\
Jawa Barat & - & Kalimantan Selatan & $04,14,21,30$ \\
Banten & - & Kalimantan Timur & - \\
Jawa Tengah & - & Kalimantan Utara & $04,21,30$ \\
DI Yogyakarta & 04,30 & Sulawesi Utara & - \\
Jawa Timur & $04,21,30$ & Gorontalo & $04,21,30$ \\
Aceh & $04,14,21,30$ & Sulawesi Tengah & $04,14,21,30$ \\
Sumatera Utara & - & Sulawesi Selatan & $11,21,30$ \\
Sumatera Barat & $04,14,21$ & Sulawesi Barat & $04,21,30$ \\
Riau & - & Sulawesi Tenggara & $04,21,30$ \\
Kepulauan Riau & - & Maluku & $21,23,30$ \\
Jambi & - & Maluku Utara & - \\
Sumatera Selatan & - & Bali & $11,21,30$ \\
Bangka Belitung & $11,21,30$ & Nusa Tenggara Barat & $11,21,30$ \\
Bengkulu & $04,14,21,30$ & Nusa Tenggara Timur & - \\
Lampung & - & Papua & $11,21,30$ \\
Kalimantan Barat & $04,14,21$ & Papua Barat & - \\
\hline \hline
\end{tabular}

Tabel 2.

Target Perbaikan Overall Efficiency SMK (Maluku Utara)

\begin{tabular}{lcccccc}
\hline \multicolumn{1}{c}{ Maluku Utara } & ADM & RGM & RKM & APM & AM & $100-$ APS \\
\hline Data Awal & 29.27 & 109.44 & 49.14 & 68.24 & 29.66 & 97.14 \\
Proportionate & - & - & - & - & 0.79 & 2.59 \\
Slack & - & -26.20 & -13.97 & -2.60 & - & - \\
Weak Projection & - & - & - & - & 30.45 & 99.72 \\
Strong Projection & - & 83.25 & 35.17 & 65.64 & 30.45 & 99.72 \\
\hline \hline
\end{tabular}

Tabel 3.

Overall Efficiency Output Oriented CRS Sekolah Menengah Kejuruan

\begin{tabular}{lclc}
\hline \multicolumn{1}{c}{ Provinsi } & CRS & \multicolumn{1}{c}{ Provinsi } & CRS \\
\hline DKI Jakarta & 0.911096 & Kalimantan Tengah & 0.916862 \\
Jawa Barat & 0.958185 & Kalimantan Selatan & 1 \\
Banten & 1 & Kalimantan Timur & 0.93181 \\
Jawa Tengah & 0.980644 & Kalimantan Utara & 1 \\
DI Yogyakarta & 0.818905 & Sulawesi Utara & 0.850223 \\
Jawa Timur & 0.923925 & Gorontalo & 0.987136 \\
Aceh & 0.819871 & Sulawesi Tengah & 0.842274 \\
Sumatera Utara & 0.82894 & Sulawesi Selatan & 0.879597 \\
Sumatera Barat & 0.863228 & Sulawesi Barat & 0.925166 \\
Riau & 0.894225 & Sulawesi Tenggara & 0.81631 \\
Kepulauan Riau & 0.894439 & Maluku & 0.840119 \\
Jambi & 0.895907 & Maluku Utara & 0.862678 \\
Sumatera Selatan & 1 & Bali & 1 \\
Bangka Belitung & 1 & Nusa Tenggara Barat & 0.849508 \\
Lampung & 0.927568 & Nusa Tenggara Timur & 0.867708 \\
Kalimantan Barat & 1 & Papua & 1 \\
Kalimantan Tengah & 0.916862 & Papua Barat & 0.872496 \\
\hline \hline
\end{tabular}

memberikan acuan atau referensi kepada provinsi yang belum efisien, untuk memudahkan membaca data maka nama provinsi akan diwakili oleh kode DMU yang ditunjukkan pada tabel 2.

Berikut merupakan hasil penentuan acuan/referensi provinsi untuk prvinsi yang belum efisien tersaji pada tabel 3 . Berdasarkan tabel 3, didapatkan beberapa provinsi yang dijadikan sebagai referensi/acuan untuk gerai yang belum efisien, terlebih ada beberapa provinsi yang beberapa kali dijadikan sebagai referensi/acuan. Provinsi yang menjadi referensi/acuan antara lain Provinsi Jawa Tengah, Provinsi Kalimantan Utara dan Provinsi Bali.

\section{C.Analisis Target Perbaikan}

Analisis target perbaikan dilakukan untuk memberikan rekomendasi kepada provinsi yang belum efisien berupa target pengurangan input atau peningkatan output. Target perbaika 
Tabel 6.

Perhitungan Scale Efficiency Sekolah Menengah Kejuruan

\begin{tabular}{lcclcc}
\hline \hline \multirow{2}{*}{ Provinsi } & \multicolumn{2}{c}{$2018 / 2019$} & \multirow{2}{*}{ Provinsi } & \multicolumn{2}{c}{$2018 / 2019$} \\
\cline { 2 - 3 } \cline { 5 - 6 } & SE & RTS & SE & RTS \\
\hline DKI Jakarta & 0.911 & DRS & Kalimantan Tengah & 0.922 & DRS \\
Jawa Barat & 0.959 & DRS & Kalimantan Selatan & 1 & CRS \\
Banten & 1 & CRS & Kalimantan Timur & 0.935 & DRS \\
Jawa Tengah & 0.981 & DRS & Kalimantan Utara & 1 & CRS \\
DI Yogyakarta & 0.819 & DRS & Sulawesi Utara & 0.854 & DRS \\
Jawa Timur & 0.927 & DRS & Gorontalo & 0.987 & DRS \\
Aceh & 0.825 & DRS & Sulawesi Tengah & 0.846 & DRS \\
Sumatera Utara & 0.837 & DRS & Sulawesi Selatan & 0.885 & DRS \\
Sumatera Barat & 0.866 & DRS & Sulawesi Barat & 0.936 & DRS \\
Riau & 0.897 & DRS & Sulawesi Tenggara & 0.829 & DRS \\
Kepulauan Riau & 0.894 & DRS & Maluku & 0.846 & DRS \\
Jambi & 0.898 & DRS & Maluku Utara & 0.886 & DRS \\
Sumatera Selatan & 1 & CRS & Bali & 1 & CRS \\
Bangka Belitung & 1 & CRS & Nusa Tenggara Barat & 0.863 & DRS \\
Bengkulu & 0.859 & DRS & Nusa Tenggara Timur & 0.878 & DRS \\
Lampung & 0.929 & DRS & Papua & 1 & CRS \\
Kalimantan Barat & 1 & CRS & Papua Barat & 0.881 & DRS \\
\hline \hline
\end{tabular}

diberikan untuk salah satu provinsi yang nilai efisiennya terkecil yaitu provinsi Provinsi Maluku Utara sebagai berikut.

Pada Tabel 4 dapat diketahui bahwa Provinsi Maluku Utara dapat meningkatkan efisiensinya dengan memproyeksikan strong efficient frontier, yaitu dengan menurunkan RGM menjadi 83.25, RKM menjadi 35.17 dan APM menjadi 65.64, namun hal ini tentu perlu dipertimbangkan, selanjutnya menaikan target AM menajadi 30.45 dan angka tetap bersekolah menjadi 99.72. Pada weak projection perlu untuk meningkatkan nilai AM menjadi 30.45 dan angka tetap bersekolah menjadi 99.72, projeksi ini dirasa lebih relevan.

\section{D.Analisis Scale Efficiency}

Untuk mendapatkan nilai scale efficiency, maka dibutuhkan perhitungan nilai efisiensi dengan asumsi constant return to scale. perhitungan overall efficiency ditunjukkan pada tabel 5 . Setelah didapatkan nilai efisiensi CRS dan VRS untuk seluruh gerai KFC, maka perhitungan scale efficiency pada tabel 6 berikut ini. Berdasarkan tabel 6 diatas diketahui terdapat 8 provinsi yang sudah peroperasi pada skala optimal, sehingga 26 provinsi beroperasi pada skala decreasing return to scale yang mengindikasikan bahwa proporsi penambahan input lebih besar dari proporsi peningkatan

\section{SIMPULAN DAN SARAN}

\section{A. Simpulan}

Berdasarkan hasil pengolahan, analisis dan pembahasan hasil penelitian terkait evaluasi efisiensi efisiensi penyelenggaraan pendidikan di Indonesia pada jenjang SMK didapatkan beberapa simpulan yaitu, hasil perhitungan efisiensi provinsi dengan output oriented VRS DEA menunjukkan bahwa provinsi dinyatakan efisien sebanyak 14 provinsi sedangkan provinsi yang dinyatakan tidak efisien sebanyak 20 provinsi. Selain itu, target perbaikan dan referensi/acuan diberikan untuk salah satu DMU dengan nilai efisiensi terkecil yaitu pada Provinsi Maluku Utara. Lebih lanjut, hasil perhitungan scale efficiency menunjukkan bahwa sebagian besar provinsi beroperasi pada skala decreasing return to scale yang menunjukkan bahwa selain pure technical efficiency, nilai efisiensi gerai dipengaruhi oleh perbedaan skala operasi.

\section{B. Limitasi}

Penelitian ini memiliki keterbatasan dan kendala yang dihadapi selama penelitian berlangsung. Keterbatasan dalam proses pengumpulan data yang menyesuaikan dengan ketersediaan data, sehingga waktu pengumpulan data lebih lama dari rencana awal.

\section{C.Saran}

Penelitian ini mengevaluasi efisiensi penyelenggaraan pendidikan di Indonesia menggunakan metode output oriented VRS DEA untuk tiap provinsi, referensi/acuan dan target perbaikan untuk provinsi yang belum efisien. Berikut beberapa rekomendasi bagi penelitian selanjutnya.Terdapat tiga saran untuk penelitian selanjutnya, saran pertama yaitu menambahkan variabel-variabel terkait yang belum digunakan dalam penelitian ini, seperti nilai ujian nasional sebagai indikator nilai kualitas. Saran kedua yaitu melakukan penelitian terkait hubungan antar variabel diatas dan mengidentifikasi variabel mana yang paling memengaruhi efisiensi gerai restoran cepat saji dengan menggunakan Tobit Regression dan Generalized Least Squares. Saran ketiga terkait dengan level yang dievaluasi, jika dalam penelitian ini level provinsi yang dievaluasi, pada penelitian selanjutnya dapat dilakukan evaluasi pada lingkup yang lebih kecil seperti pada level kota/kabupaten hingga level tiap sekolah, sehingga target perbaikan lebih merujuk pada kondisi tiap kota atau sekolah. Provinsi dengan nilai efisiensi terkecil pada penelitian ini dapat menjadi acuan untuk perlu dianalisis lebih mendalam dengan menghitung efisiensi tiap kota/kabupaten di area provinsi tersebut.

\section{DAFTAR PUSTAKA}

[1] D. Andreas, "Indeks SDM Bank Dunia 2018: Singapura Peringkat 1, Indonesia ke-87," tirto.id, 11-Aug-2018. [Online]. Available: https://tirto.id/indeks-sdm-bank-dunia-2018-singapura-peringkat-1indonesia-ke-87-c6jN. [Accessed: 15-Jun-2020].

[2] Rubrik Finalsialku, "Kenali dan Pahami Serba Serbi Dunia Pendidikan di Indonesia," finalsialku.com, 18-Feb-2019. [Online]. Available: https://www.finansialku.com/dunia-pendidikan-di-indonesia/. [Accessed: 15-Jun-2020].

[3] Advertorial detikNews, "Alokasi Dana Pendidikan 20\% APBN, Begini Caranya Biar Tepat Sasaran," detik.com, 17-Aug-2019. [Online]. Available: https://news.detik.com/adv-nhl-detikcom/d-4669262/alokasidana-pendidikan-20-apbn-begini-caranya-biar-tepat-sasaran. [Accessed: 15-Jun-2020].

[4] S. Fatimah and U. Mahmudah, "Two-Stage Data Envelopment Analysis ( DEA ) for Measuring the Efficiency of Elementary Schools in Indonesia," Int. J. Environ. Sci. Educ., vol. 12, no. 8, pp. 1971-1987, 2017.

[5] H. Mahmudi, M. Ismail, C. F. Ananda, and M. Khusaini, "An Analysis of Technical Efficiency of Education Organizer (A Case Study at Junior High School in Mataram City - West Nusa Tenggara)," Int. J. Bus. Manag. Invent. ISSN (Online, vol. 3, no. 7, pp. 2319-8028, 2014.

[6] U. Mahmudah, S. Suhartono, and A. D. Rohayana, "A Robust Data Envelopment Analysis for Evaluating Technical Efficiency of Indonesian High Schools," J. Pendidik. IPA Indones., vol. 7, no. 1, pp. 114-121, 2018, doi: 10.15294/jpii.v7i1.9883.

[7] A. Haryadi, "Analisis Efisiensi Teknis Bidang Pendidikan (Penerapan Data Envelopment Analysis)," Magister Perenc. dan Kebijak. publik Fak. Ekon. Univ. Indones., 2011.

[8] E. Sutrisno, "Manajemen Sumber Daya Manusia Edisi pertama," Jakarta Kencana Prenada Media Gr., 2009.

[9] I. G. A. Rai, Audit kinerja pada sektor publik: konsep, praktik, studi kasus. 
Jakarta: Salemba Empat, 2008.

[10] J. S. Mulyadi, Sistem Perencanaan dan Pengendalian Manajemen. Yogyakarta: Aditya Media, 1999.

[11] M. D. Hadad, W. Santoso, E. Mardanugraha, and D. Illyas, "Pendekatan Parametrik Untuk Efisiensi Perbankan Indonesia," Bank Indones., pp. 127, 2003.

[12] P. Andersen and N. C. Petersen, "A Procedure for Ranking Efficient Units in Data Envelopment Analysis," Manage. Sci., vol. 39, no. 10, pp. 12611264, 1993, doi: 10.1287/mnsc.39.10.1261.

[13] W. W. . Cooper, L. M. Seiford, and K. Tone, Data Envelopment Analysis: A Comprehensive Text with Models, Applications, References and DEASolver Software, 3rd ed., vol. 52, no. 12. Boston / Dordrecht / London: Kluwer Academic Publisher, 2001.
[14] A. Charnes, W. W. Cooper, and E. Rhodes, "Measuring the efficiency of decision making units," Eur. J. Oper. Res., vol. 2, no. 6, pp. 429-444, 1978, doi: 10.1016/0377-2217(78)90138-8.

[15] S. Handoum, "Analisis Dampak Kebijakan Perikanan Terhadap Pertumbuhan Ekonomi dan Produktivitas Daerah (Studi kasus kebijakan perikanan di KabupatenKlungkung - Propinsi Bali)," Theses Ind. Eng. RTi 338.959 86 Han a, 2005, pp. 1-75, 2006.

[16] R. . Banker, A. Charnes, and W. W. Cooper, "Some Models for Estimaing Technical and Scale Inefficiencies in Data Envelopment Analysis," Manage. Sci., vol. 30, no. 9, pp. 1078-1092, 1984, doi: 00251909/84/3009/1078501.25.

[17] A. C. Worthington, "Technical efficiency and technological change in Australian building societies," Abacus, vol. 36, no. 2, pp. 189-197, 2000, doi: 10.1111/1467-6281.00059. 